\title{
SunLine Transit Agency Fuel Cell Transit Bus: Fifth Evaluation Report
}

Leslie Eudy, National Renewable Energy Laboratory Kevin Chandler, Battelle

Link to Appendices
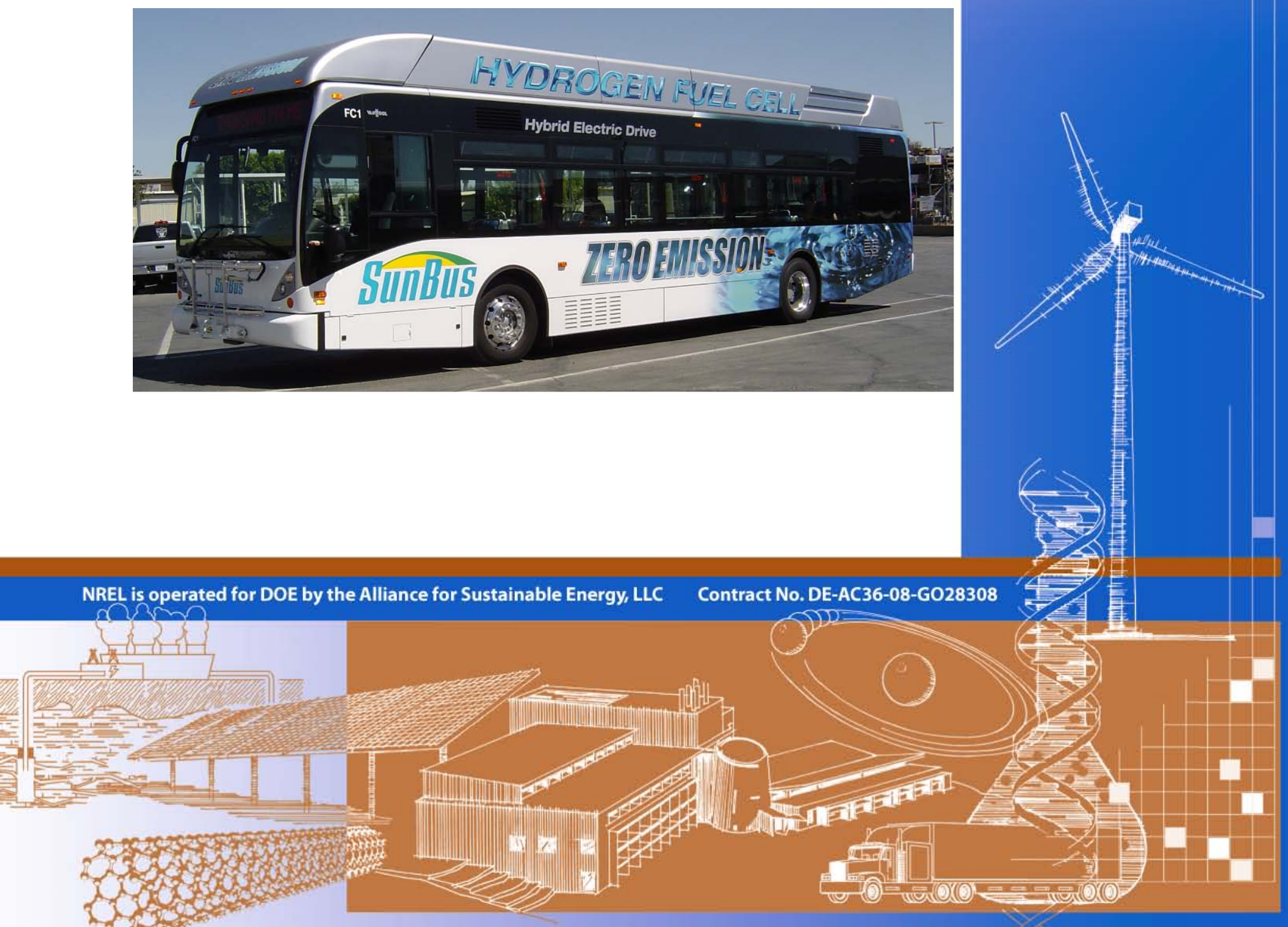


\section{SunLine Transit Agency}

Fuel Cell Transit Bus:

Fifth Evaluation Report

Technical Report NREL/TP-560-46346-1

August 2009

Leslie Eudy, National Renewable Energy Laboratory Kevin Chandler, Battelle

Prepared under Task No. FC08.7820

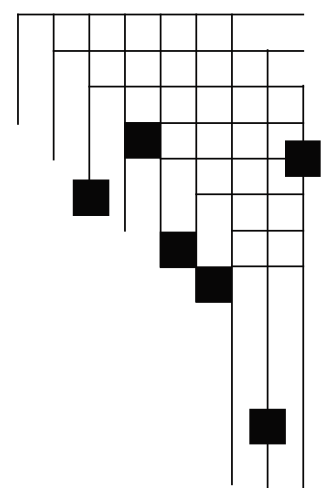

National Renewable Energy Laboratory

1617 Cole Boulevard, Golden, Colorado 80401-3393

303-275-3000 • www.nrel.gov

NREL is a national laboratory of the U.S. Department of Energy

Office of Energy Efficiency and Renewable Energy

Operated by the Alliance for Sustainable Energy, LLC

Contract No. DE-AC36-08-GO28308 


\section{NOTICE}

This report was prepared as an account of work sponsored by an agency of the United States government. Neither the United States government nor any agency thereof, nor any of their employees, makes any warranty, express or implied, or assumes any legal liability or responsibility for the accuracy, completeness, or usefulness of any information, apparatus, product, or process disclosed, or represents that its use would not infringe privately owned rights. Reference herein to any specific commercial product, process, or service by trade name, trademark, manufacturer, or otherwise does not necessarily constitute or imply its endorsement, recommendation, or favoring by the United States government or any agency thereof. The views and opinions of authors expressed herein do not necessarily state or reflect those of the United States government or any agency thereof.

Available electronically at http://www.osti.gov/bridge

Available for a processing fee to U.S. Department of Energy and its contractors, in paper, from:

U.S. Department of Energy

Office of Scientific and Technical Information

P.O. Box 62

Oak Ridge, TN 37831-0062

phone: 865.576 .8401

fax: 865.576 .5728

email: mailto:reports@adonis.osti.gov

Available for sale to the public, in paper, from:

U.S. Department of Commerce

National Technical Information Service

5285 Port Royal Road

Springfield, VA 22161

phone: 800.553.6847

fax: 703.605.6900

email: orders@ntis.fedworld.gov

online ordering: http://www.ntis.gov/ordering.htm 


\section{Acknowledgements}

This evaluation at SunLine Transit Agency would not have been possible without the support and cooperation of many people. The authors thank the following:

U.S. Department of Energy

John Garbak

U.S. Federal Transit Administration

Walter Kulyk

Christina Gikakis

National Renewable Energy Laboratory

Keith Wipke

Terry Penney

SunLine

C. Mikel Oglesby

Tommy Edwards

Polo Del Toro

Ed Gallardo

Shawn Craycraft

Karen Thomas

Mike Hayes

UTC Power

Dave Boudreau

Matthew Riley

Rakesh Radhakrishnan

ISE

Paul Scott

Kevin Stone

Dave Ticonchuk

HyRadix

Terry Schuster 


\section{Acronyms and Abbreviations}

ASME

AQMD

CARB

$\mathrm{CNG}$

DGE

DOE

FCB

$\mathrm{ft}$.

FTA

GGE

HHICE

hp

HVAC

in.

$\mathrm{kg}$

$\mathrm{kW}$

lb.

MBRC

mpdeg

mph

NFCBP

NREL

PMI

psi

$\mathrm{RC}$
American Society of Mechanical Engineers

Air Quality Management District

California Air Resources Board

compressed natural gas

diesel gallon equivalent

U.S. Department of Energy

fuel cell bus

feet

Federal Transit Administration

gasoline gallon equivalent

hydrogen hybrid internal combustion engine

horsepower

heating, ventilation, and air conditioning

inches

kilogram

kilowatts

pounds

miles between roadcalls

miles per diesel equivalent gallon

miles per hour

National Fuel Cell Bus Program

National Renewable Energy Laboratory

preventive maintenance inspection

pounds per square inch

roadcall 


\section{Executive Summary}

This report describes operations at SunLine Transit Agency for a prototype fuel cell bus and five new compressed natural gas $(\mathrm{CNG})$ buses. SunLine provides public transit services to the Palm Springs area of California. The Department of Energy's (DOE) National Renewable Energy Laboratory (NREL) has been evaluating this fuel cell bus to document the results and help determine the progress of the technology toward technology readiness. This is the fifth evaluation report for this site, and it focuses on results and experiences from November 2008 through June 2009. These results are an addition to those provided in the previous four evaluation reports.

SunLine has operated its fuel cell bus with UTC Power's newest version fuel cell power system, which was installed in April 2008. This new version of the fuel cell power system is expected to perform much better in respect to the number of operating hours than the previous versions. During the data period for the report, the fuel cell bus operated 12,529 miles and 908 hours (average operating speed of $13.8 \mathrm{mph}$ ). The totals since the new fuel cell power system was installed are 23,990 miles and 1,793 hours. UTC Power reports that there are no indications of the early power degradation that earlier versions experienced by this point.

During the evaluation period, the hydrogen fueling station provided 4,729 $\mathrm{kg}$ of hydrogen at an average cost of $\$ 12.15$ per $\mathrm{kg}$ including parts and labor, amortization of the equipment, and natural gas and utilities. SunLine indicates that the best steady-state operating point for the reformer system would be around $\$ 8$ per kg or possibly less. The on-site CNG station provided fuel at an average of $\$ 1.07$ per GGE.

The fuel cell bus was not available as often during this evaluation period compared with previous reporting periods. This lower availability was a result of two significant downtime periods that were not due to issues with the fuel cell system. The first was a problem with the traction batteries that could not be resolved quickly because of lack of funding for this project. The second downtime period occurred when the hydrogen fuel production system was out of service for an upgrade and repair. If these two incidents are factored out of the calculation, the bus had an availability of $74 \%$, which is consistent with the rest of the time period after installation of the new fuel cell system. The fuel economy continues to be significantly higher for the fuel cell bus compared with the CNG buses - more than two times higher. Miles between roadcalls (MBRC) for the fuel cell bus has continued to be much lower than the conventional buses. The maintenance costs for the fuel cell bus are 1.7 times higher than the CNG buses; however, all of the fuel cell propulsion-system parts have been covered under warranty.

Table ES-1 provides a summary of results for several categories of data presented in this report. 
Table ES-1. Summary of Evaluation Results

\begin{tabular}{|l|c|c|}
\hline \multicolumn{1}{|c|}{ Data Item } & Fuel Cell & CNG \\
\hline Number of Buses & 1 & 5 \\
\hline Data Period & $11 / 08-6 / 09$ & $11 / 08-6 / 09$ \\
\hline Number of Months & 8 & 8 \\
\hline Total Mileage in Period & 12,529 & 198,990 \\
\hline Average Monthly Mileage per Bus & 1,566 & 4,975 \\
\hline Availability (85\% is target) & $51 \%$ & $95 \%$ \\
\hline Fuel Economy (Miles/kg or GGE) & 7.14 & 3.39 \\
\hline Miles between Roadcalls (MBRC) - All & 2,506 & 19,899 \\
\hline MBRC - Propulsion Only & 3,132 & 49,748 \\
\hline Total Maintenance, \$/mile & 0.43 & 0.25 \\
\hline Maintenance - Propulsion Only, \$/mile & 0.16 & 0.05 \\
\hline
\end{tabular}




\section{Table of Contents}

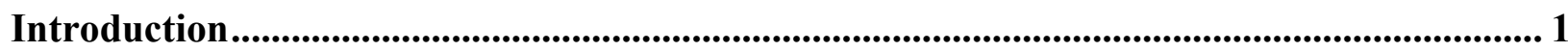

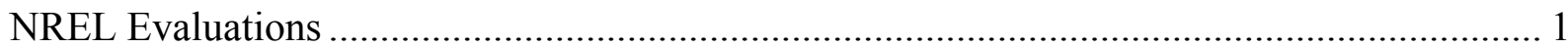

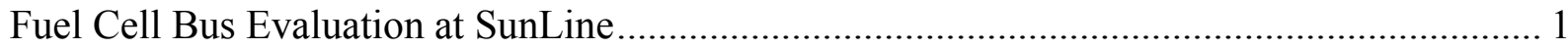

Hydrogen and CNG Fueling ............................................................................................................... 3

Evaluation Results ............................................................................................................................ 6

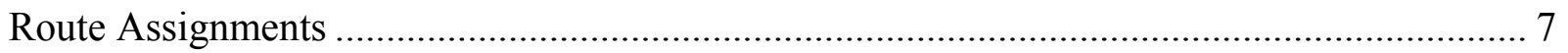

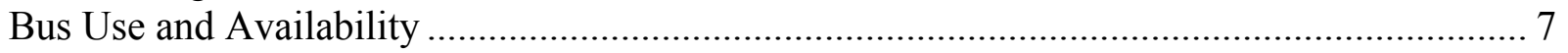

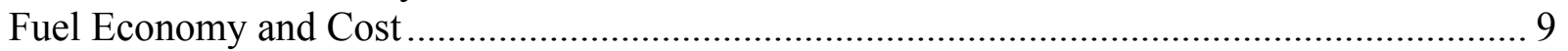

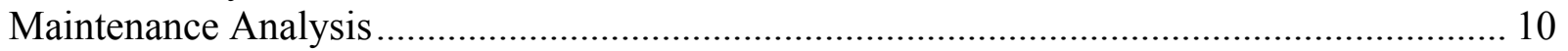

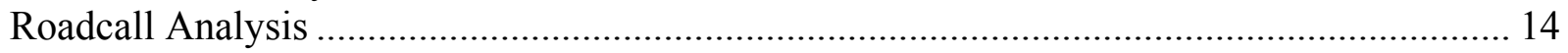

Demonstration Achievements and Challenges .................................................................................... 15

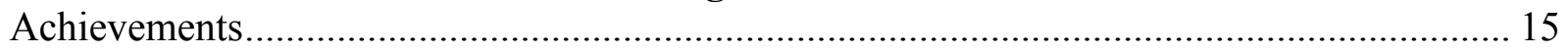

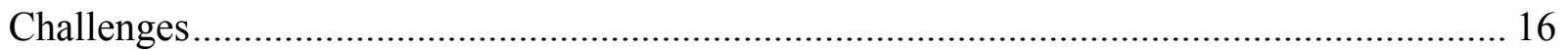

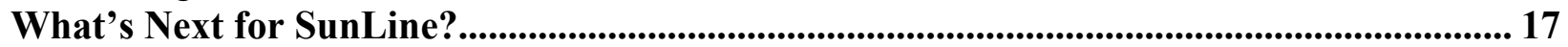

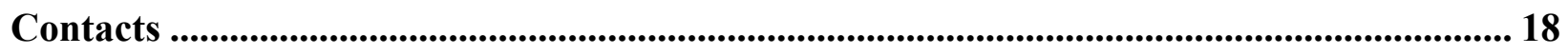

References and Related Reports....................................................................................................... 19

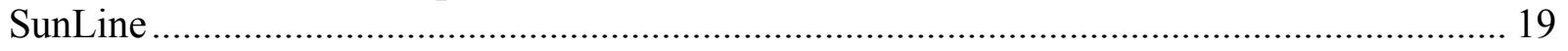

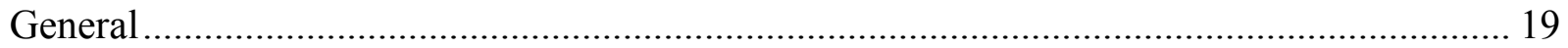

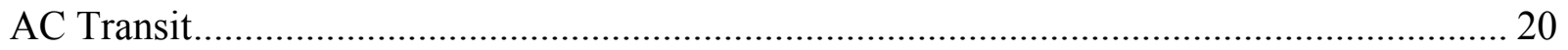

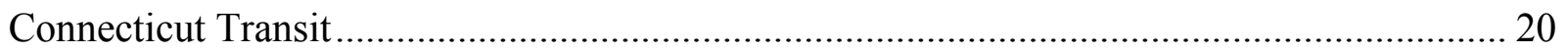

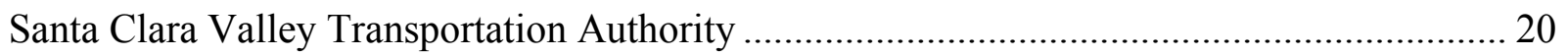




\section{Introduction}

SunLine Transit Agency ${ }^{1}$ has been operating one fuel cell bus in revenue service in the Palm Springs, California area, since January 2006. The early operation of this bus has been documented in four previous evaluation reports from the U.S. Department of Energy (DOE) and the National Renewable Energy Laboratory (NREL). ${ }^{2,3,4,5}$ This report continues the evaluation of the fuel cell bus and five compressed natural gas $(\mathrm{CNG})$ buses as a baseline.

\section{NREL Evaluations}

NREL has been evaluating alternative fuel and advanced propulsion transit buses for DOE and the Federal Transit Administration (FTA) since the early 1990s. NREL's first evaluation of hydrogen fuel cell transit buses for DOE was in 2000 and continues with this evaluation at SunLine. These evaluations focus on determining the status of hydrogen and fuel cell systems and corresponding infrastructure in transit applications to help DOE assess the progress toward technology readiness. NREL uses a standard data-collection and analysis protocol originally developed for DOE heavy-duty vehicle evaluations, and a joint evaluation plan has been documented for transit bus evaluations ${ }^{6}$. Appendix A describes NREL's transit bus evaluation activities for DOE and FTA.

\section{Fuel Cell Bus Evaluation at SunLine}

SunLine Transit Agency provides public transit services to California's Coachella Valley. Headquartered in Thousand Palms, SunLine's service area of over 1,100 square miles includes nine member cities and a portion of Riverside County. SunLine has proactively adopted clean fuel technologies in their fleet, beginning with compressed natural gas (CNG) buses in 1994. Since then, the agency has tested many advanced technologies including buses that run on a blend of hydrogen and CNG, battery electric power, and fuel cells. Appendix B provides more information on SunLine.

In January 2006, SunLine began demonstrating one prototype fuel cell bus jointly developed by Van Hool, UTC Power, and ISE Corporation. The prototype fuel cell bus features an ISE electric hybrid drive system with a UTC Power PureMotion ${ }^{7} 120$ Fuel Cell Power System and ZEBRA batteries for energy storage. The bus is shown in Figure 1.

\footnotetext{
${ }^{1}$ SunLine Transit Agency Web site: www.sunline.org

${ }^{2}$ SunLine Transit Agency, Hydrogen-Powered Transit Buses: Preliminary Evaluation Results, February 2007, NREL/TP-560-41001, www.nrel.gov//hydrogen/pdfs/41001.pdf

${ }^{3}$ SunLine Transit Agency, Hydrogen-Powered Transit Buses: Evaluation Results Update, September 2007, NREL/TP-560-42080, www.nrel.gov/hydrogen/pdfs/42080.pdf

${ }^{4}$ SunLine Transit Agency, Hydrogen-Powered Transit Buses: Third Evaluation Report and Appendices, June 2008, NREL/TP-560-43741-1, www.nrel.gov/hydrogen/pdfs/43741-1.pdf, and appendices NREL/TP/560-43741-2, www.nrel.gov/hydrogen/pdfs/43741-2.pdf

${ }_{5}^{5}$ SunLine Transit Agency, Fuel Cell Transit Bus: Fourth Evaluation Report and Appendices, January 2009, NREL/TP-560-44646-1, www.nrel.gov/hydrogen/pdfs/44646-1.pdf, and Appendices NREL/TP/560-44646-2, www.nrel.gov/hydrogen/pdfs/44646-2.pdf

${ }^{6}$ Hydrogen and Fuel Cell Transit Bus Evaluations: Joint Evaluation Plan for the U.S. Department of Energy and the Federal Transit Administration, NREL/MP-560-42781-1, May 2008, www.nrel.gov/hydrogen/pdfs/42781-1.pdf.

${ }^{7}$ PureMotion is a trademark of UTC Power.
} 


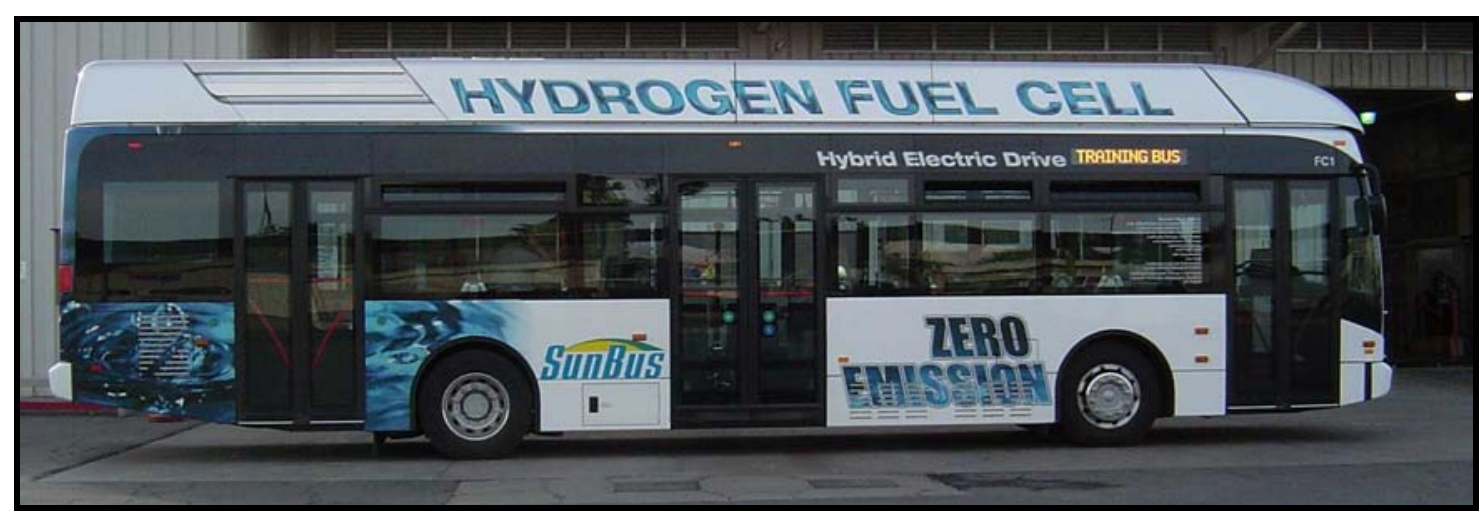

Figure 1. Fuel cell transit bus at SunLine

This report includes operations at SunLine for the fuel cell transit bus in revenue service. Five compressed natural gas $(\mathrm{CNG})$ buses operating from the same SunLine location are being used as a baseline comparison. Previous reports included data on SunLine's 2005 model year Orion CNG buses as a baseline. For this report, we have collected data on five new CNG buses built by New Flyer. Over the last two years, SunLine has been replacing all of its older CNG buses as they reached end-of-life. The 2008 model year New Flyer CNG buses use Cummins Westport ISL $\mathrm{G}$ natural gas engines that are designed to meet 2010 emission regulations (see Figure 2). Appendix $\mathrm{C}$ provides more detail about the bus technologies included in this evaluation.

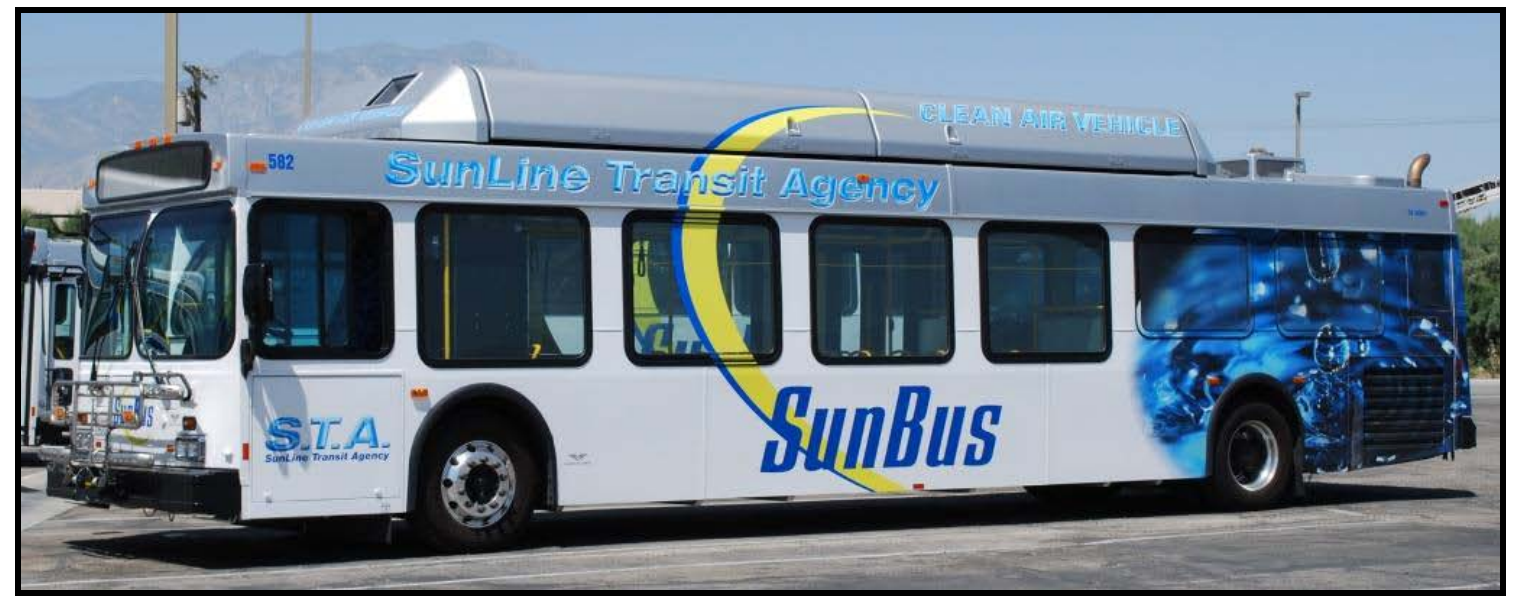

Figure 2. New Flyer CNG bus at SunLine

This fifth evaluation report describes results and experiences with the fuel cell and CNG buses since the last report. The data results are focused on the period from November 2008 through June 2009. In April 2008, the newest version fuel cell power system from UTC Power was installed in the fuel cell bus. DOE and NREL have continued to collect data on the bus to validate performance improvements resulting from the fuel cell system update. The evaluation for the hybrid hydrogen internal combustion engine bus (HHICE) has concluded; however, this report includes the fueling data on that bus to evaluate performance of the hydrogen station. 


\section{Hydrogen and CNG Fueling}

Hydrogen fuel is supplied at SunLine by a HyRadix natural gas reformer. The fuel is compressed to 5,000 psi and dispensed into the buses. CNG is brought into the SunLine property via a high-pressure natural gas line and then compressed to 3,600 psi for delivery into the vehicles. Appendix D provides general descriptions of SunLine's hydrogen and CNG fueling infrastructure along with maintenance facilities.

SunLine provides both hydrogen and CNG for purchase at its public dispensing island. Because of this, SunLine is required to track all of its fueling events in gasoline gallon equivalent (GGE) units to comply with state fuel-sale regulations. In the case of hydrogen, the unit used is typically kilograms $(\mathrm{kg})$ — one kg contains essentially the same energy as a GGE for fueleconomy calculations. This report presents both GGE (kg for hydrogen) and diesel gallon equivalent (DGE) for hydrogen and CNG fuel consumption. The end of Appendix E shows energy-conversion calculations for GGE and DGE.

Fueling Data Analysis - Figure 3 shows the average hydrogen dispensed per day into both of the hydrogen-fueled buses from November 2008 through June 2009. The calculation for this rate includes only the days in which the station dispensed hydrogen. The station was used at least once per day to fill at least one of the two hydrogen buses for $62 \%$ of the calendar days during the period. The overall average daily use was $31.3 \mathrm{~kg}$ per day. During this period, SunLine dispensed a total of 4,729 kg of hydrogen. The lower usage in December 2008 through February 2009 was because of the fuel cell bus being out of service. Only the HHICE bus was fueled during that time. The lowest point for fuel use during the data period was during March 2009. The reformer was down most of that month for a component upgrade. This upgrade was necessary to address an issue discovered by HyRadix during long-term testing at other reformer sites.

Figure 4 shows the distribution of hydrogen amounts dispensed per fill by bus type. The two buses were filled a total of 217 times during the evaluation period for a total of $4,637.6 \mathrm{~kg} .{ }^{8}$ The fuel cell bus averaged $17.8 \mathrm{~kg}$ per fill while the HHICE bus fuelings averaged $24.2 \mathrm{~kg}$ per fill. Figure 5 shows a cumulative fueling rate histogram for the SunLine hydrogen station from November 2008 through May 2009. The overall average fueling rate was $1.0 \mathrm{~kg}$ per minute, and the average time for a fill was 17.7 minutes.

\footnotetext{
${ }^{8}$ This total is slightly lower than that shown for Figure 3. If the time for the fueling was not captured in data collection, Figures 4 and 5 exclude that fueling data.
} 


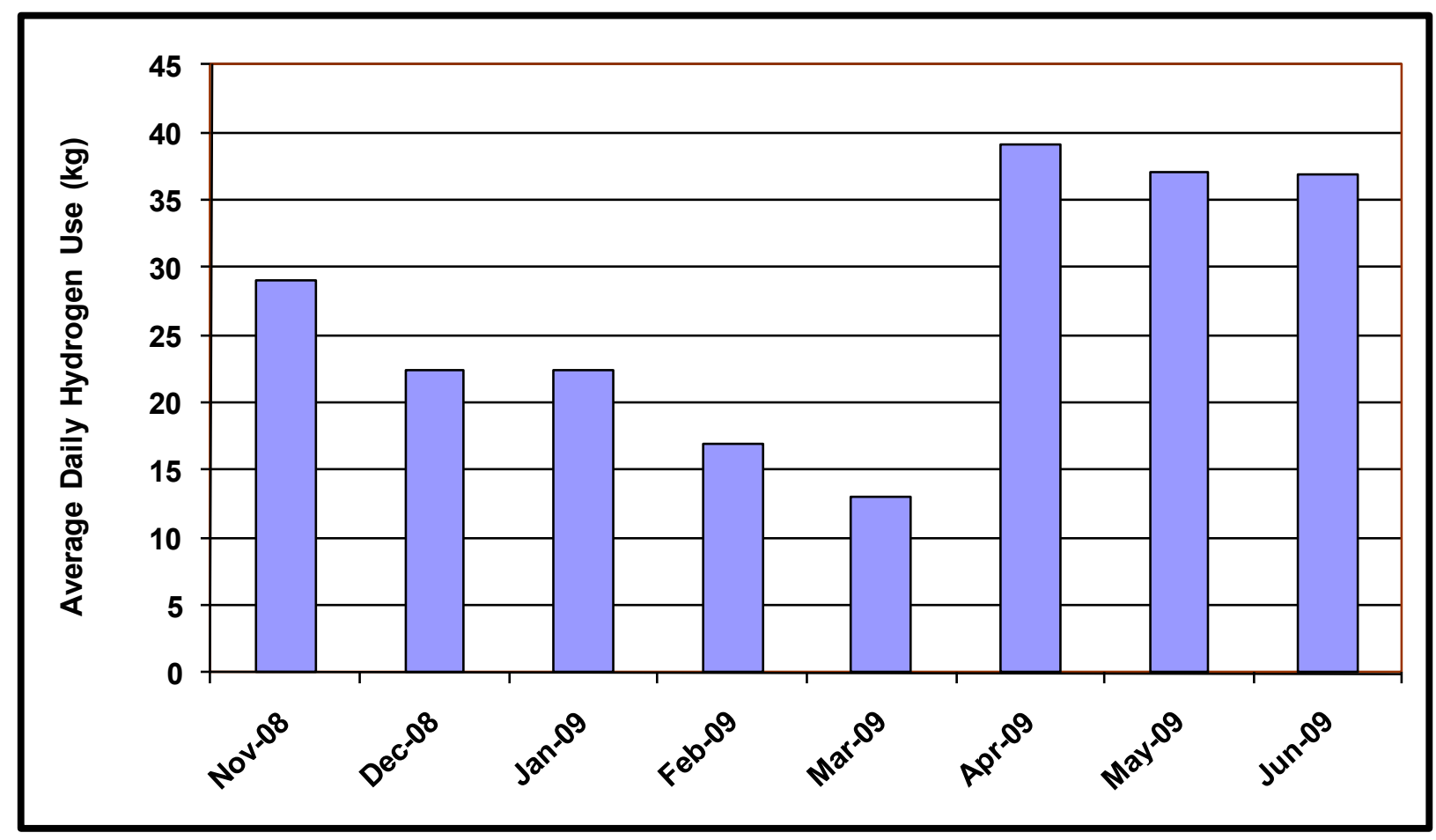

Figure 3. Average hydrogen dispensed per day (excluding 0 kg days)

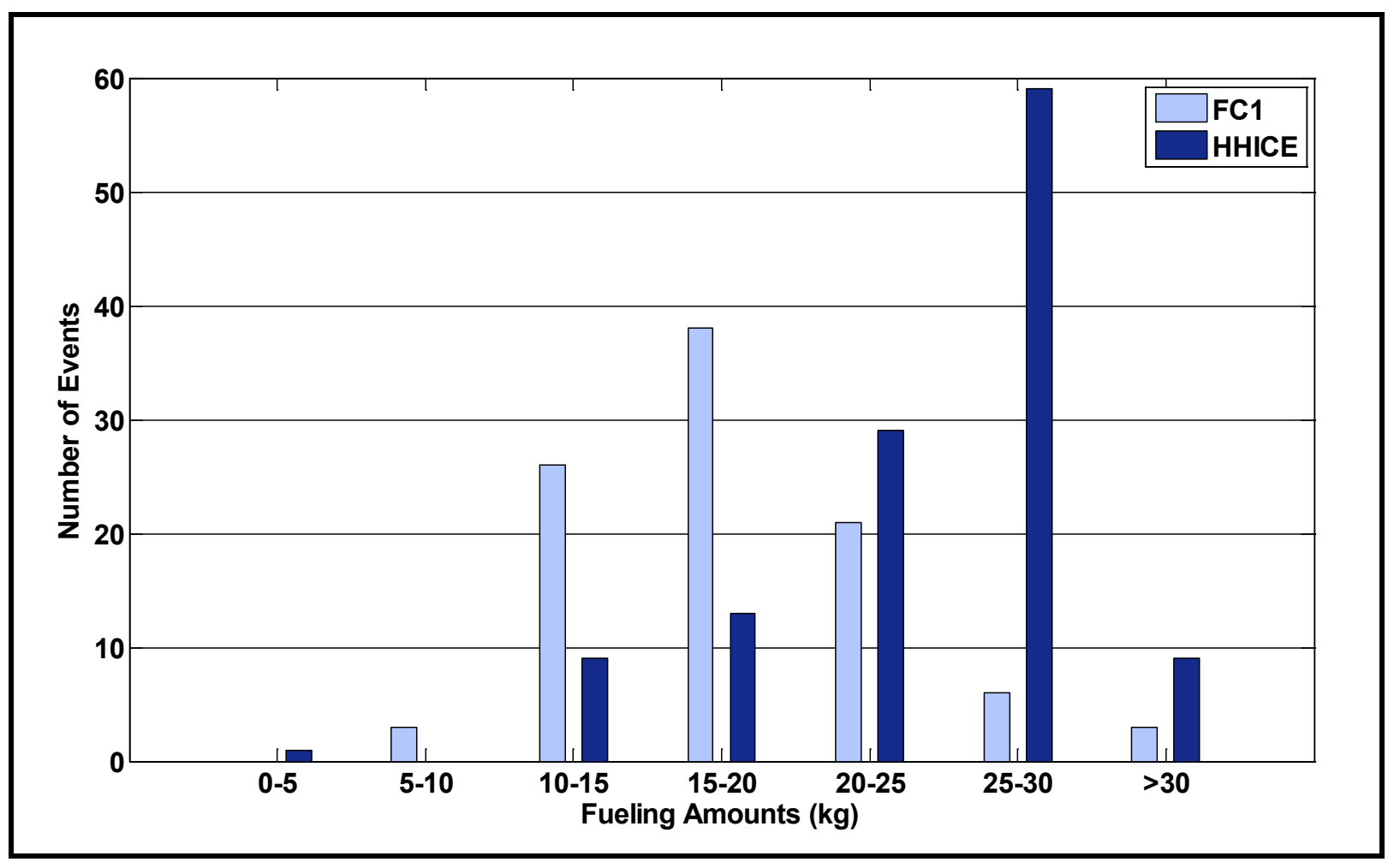

Figure 4. Distribution of fueling amounts 


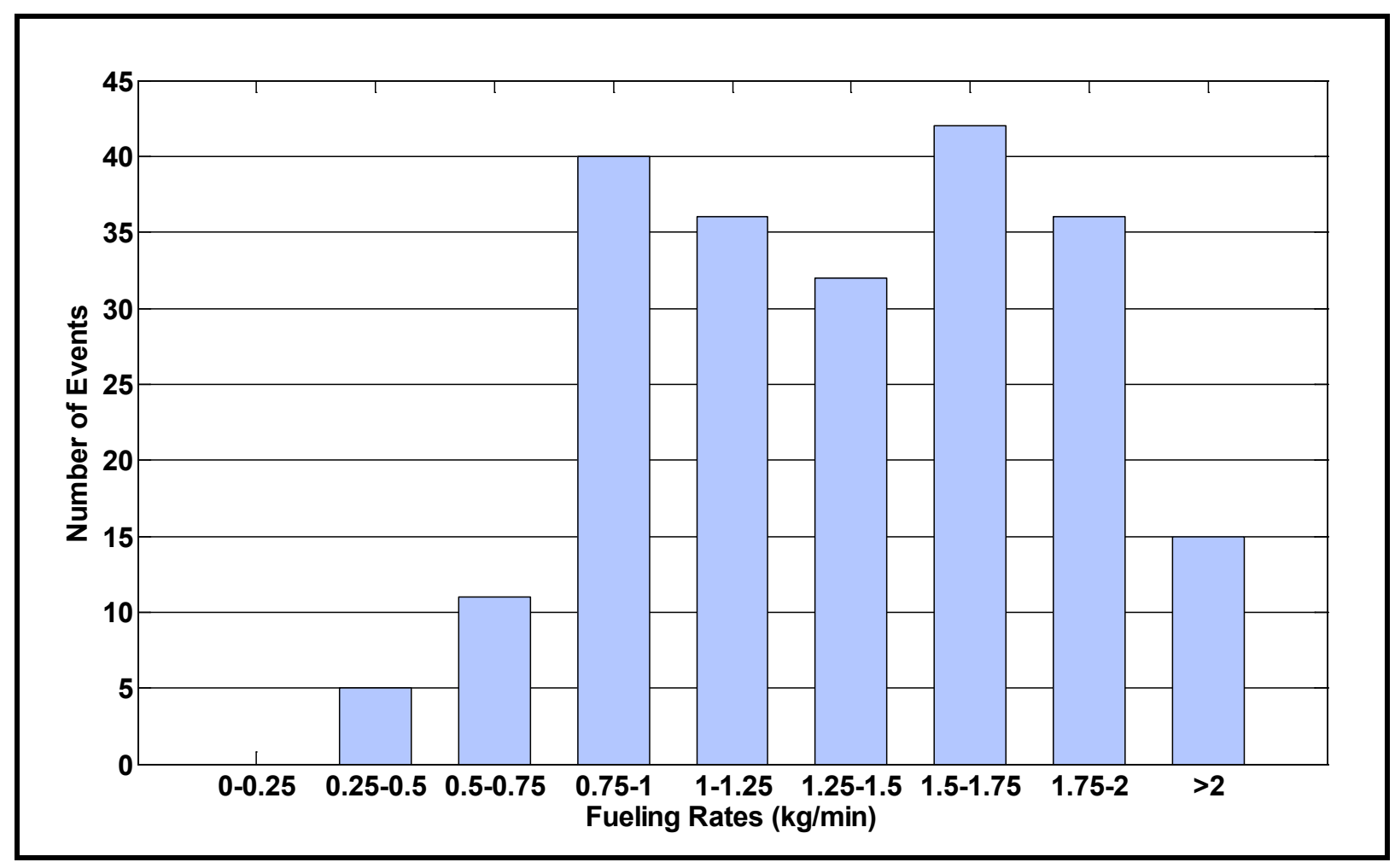

Figure 5. Cumulative fueling rate histogram

Hydrogen fuel costs at SunLine consist of the cost of natural gas for the reformer, maintenance of the station equipment, and capital cost amortization. SunLine performs the maintenance of the station including parts and labor. The average cost for hydrogen during the evaluation period was $\$ 12.15$ per $\mathrm{kg}$ (monthly costs ranged from a low of $\$ 6.50 / \mathrm{kg}$ to a high of $\$ 158 / \mathrm{kg}$ ). Lower use of the station (when the buses were out of service) and higher maintenance for the reformer during March were contributors to higher monthly costs. Figure 6 shows the monthly station use and hydrogen cost per $\mathrm{kg}$ since January 2008. DOE's target for hydrogen cost $(\$ 3 / \mathrm{kg})$ is also included. The figure illustrates the relationship between high hydrogen costs and low station use. The peak cost during the period was for the month the reformer was down for repair. The cost of that repair factors into the total hydrogen cost for that month. SunLine indicates that the best steady-state operating point for the reformer system would bring the average cost of hydrogen to around $\$ 8$ per $\mathrm{kg}$. This cost estimate is used in the cost calculations for the data results in the next section. 


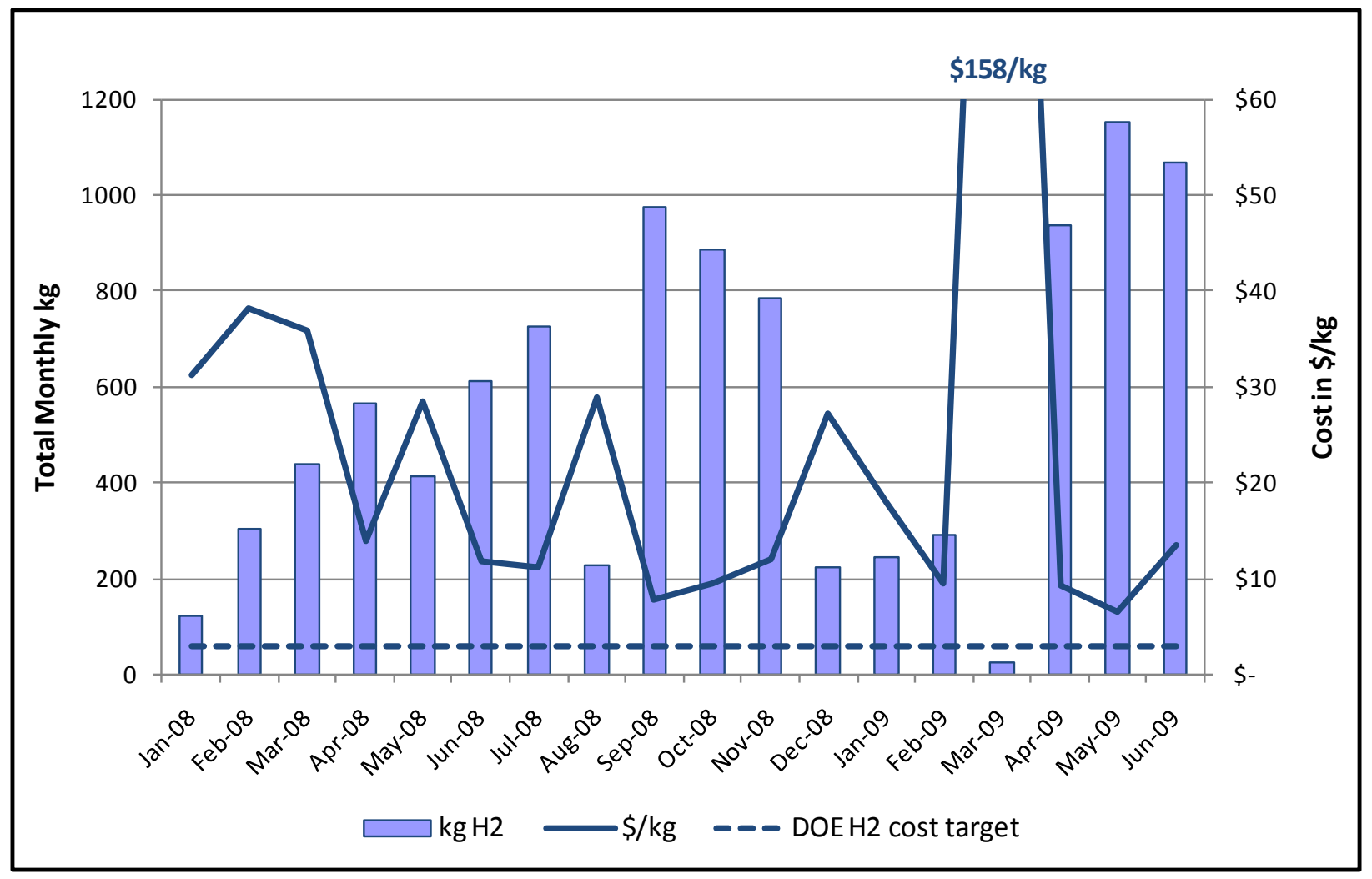

Figure 6. Comparison of monthly hydrogen use and cost per $\mathrm{kg}$

SunLine supplies CNG fuel to users in its area, and the fueling station is accessible to the public. The high volume of natural gas use has allowed SunLine to command a low cost as a commodity user. During the evaluation period, the CNG price at the dispenser for SunLine (not the public price) was $\$ 1.07$ per GGE. This price includes all costs - natural gas, maintenance, and station amortization.

\section{Evaluation Results}

The fuel cell bus at SunLine was originally placed into revenue service in January 2006. The focus of this evaluation report is on the most-recent operating data for the fuel cell bus and CNG buses. The evaluation period in this report includes data from November 2008 through June 2009. As mentioned previously, the baseline buses used for this report were from SunLine's newest order of CNG buses. Those New Flyer CNG buses began delivery in November of 2008. The evaluation results include operation of the selected CNG buses from November 2008 through June 2009. (Note: Not all the CNG buses were in service for the entire month of November.) Appendix E provides a summary of all data. Appendix F provides a data summary in SI (metric) units.

This fuel cell bus is considered prototype technology in the commercialization process. The analysis and comparison discussions with standard CNG buses help create a baseline to measure the progress of this hydrogen propulsion technology. There is no intent to consider this implementation of a fuel cell bus as commercial (or full revenue transit service). The evaluation 
focuses on documenting progress and opportunities to improve the vehicle, infrastructure, and procedures.

\section{Route Assignments}

In general, buses at the two SunLine operating locations are dispatched randomly. The overall system average operating speed at SunLine is $13.2 \mathrm{mph}$. The fuel cell bus has been used exclusively on Line 50 (average speed of $14.1 \mathrm{mph}$ ). In-service data for the fuel cell bus during the evaluation period indicate an average operating speed of $13.8 \mathrm{mph}$ based on mileage and fuel cell system operating hours. The CNG buses have been randomly dispatched with heavy use on Line $111(30 \%$ of the time - average speed of $14.3 \mathrm{mph})$ and Line 30 (16\% of the time - average speed of $12 \mathrm{mph})$.

\section{Bus Use and Availability}

Bus use and availability indicates reliability. Lower bus use may indicate downtime for maintenance or purposeful reduction of planned work for the buses. This section provides a summary of bus use and availability for the fuel cell and CNG buses.

The fuel cell bus has planned service of up to seven days per week. For the fuel cell bus, total mileage accumulation for the evaluation period was 12,529 miles, and the fuel cell system accumulated 908 hours, which indicates an average speed of $13.8 \mathrm{mph}$. Since the start of revenue operation of the fuel cell bus, the total mileage is 76,326 with 5,820 total hours for an overall average speed of $13.1 \mathrm{mph}$. This average is only slightly slower than the overall 13.2mph average speed for all SunLine routes.

Table 1 summarizes the average monthly mileage accumulation by bus and study group for the evaluation period. Using the CNG buses as the baseline, the fuel cell bus had an average monthly mileage $31 \%$ that of the CNG buses. This percentage is slightly less than that reported previously due to downtime of the reformer and significant downtime for the fuel cell bus.

Table 1. Average Monthly Mileage (Evaluation Period)

\begin{tabular}{|c|c|c|c|c|c|}
\hline Bus & $\begin{array}{c}\text { Starting } \\
\text { Hubodometer }\end{array}$ & $\begin{array}{c}\text { Ending } \\
\text { Hubodometer }\end{array}$ & $\begin{array}{c}\text { Total } \\
\text { Mileage }\end{array}$ & Months & $\begin{array}{c}\text { Monthly } \\
\text { Average }\end{array}$ \\
\hline FC1 & $\mathbf{6 6 , 6 6 2}$ & $\mathbf{7 9 , 1 9 1}$ & $\mathbf{1 2 , 5 2 9}$ & $\mathbf{8}$ & $\mathbf{1 , 5 6 6}$ \\
\hline 603 CNG & 2,752 & 46,798 & 44,046 & 8 & 5,506 \\
\hline 604 CNG & 2,574 & 39,783 & 37,209 & 8 & 4,651 \\
\hline 605 CNG & 2,683 & 40,869 & 38,186 & 8 & 4,773 \\
\hline 606 CNG & 2,554 & 43,977 & 41,423 & 8 & 5,178 \\
\hline 608 CNG & 2,522 & 40,648 & 38,126 & 8 & 4,766 \\
\hline Total CNG & & & $\mathbf{1 9 8 , 9 9 0}$ & $\mathbf{4 0}$ & $\mathbf{4 , 9 7 5}$ \\
\hline
\end{tabular}

Another measure of reliability is availability - the percent of time that the buses are planned for operation compared with the time the buses are actually available for that planned operation. Figure 7 shows the monthly average availability for each of the study bus groups. As shown in the chart, the availability goal is $85 \%$ for all buses. Availability for all of NREL's evaluations is calculated by including the planned service days, which is typically every weekday. Weekends and holidays are included in the calculation only if the bus operated in service on those days. If a 
bus does not operate on the weekend or a holiday, it is not counted as unavailable. This strategy applies to both the fuel cell bus and the CNG buses.

The fuel cell bus was available $51 \%$ of the time during the evaluation period. This is much lower than the availability reported in the last report (76\%). The bus was out of service for an extended period from late November 2008 through mid-February 2009. Although the bus was down for battery problems, the length of the downtime was because of budget issues at the transit agency. The repair was delayed while SunLine resolved those issues. The downtime for the reformer during March 2009 was another factor affecting the lower availability of the fuel cell bus. Removal of those three months from the calculation brings the availability up to $74 \%$, which is consistent with the data from the last report.

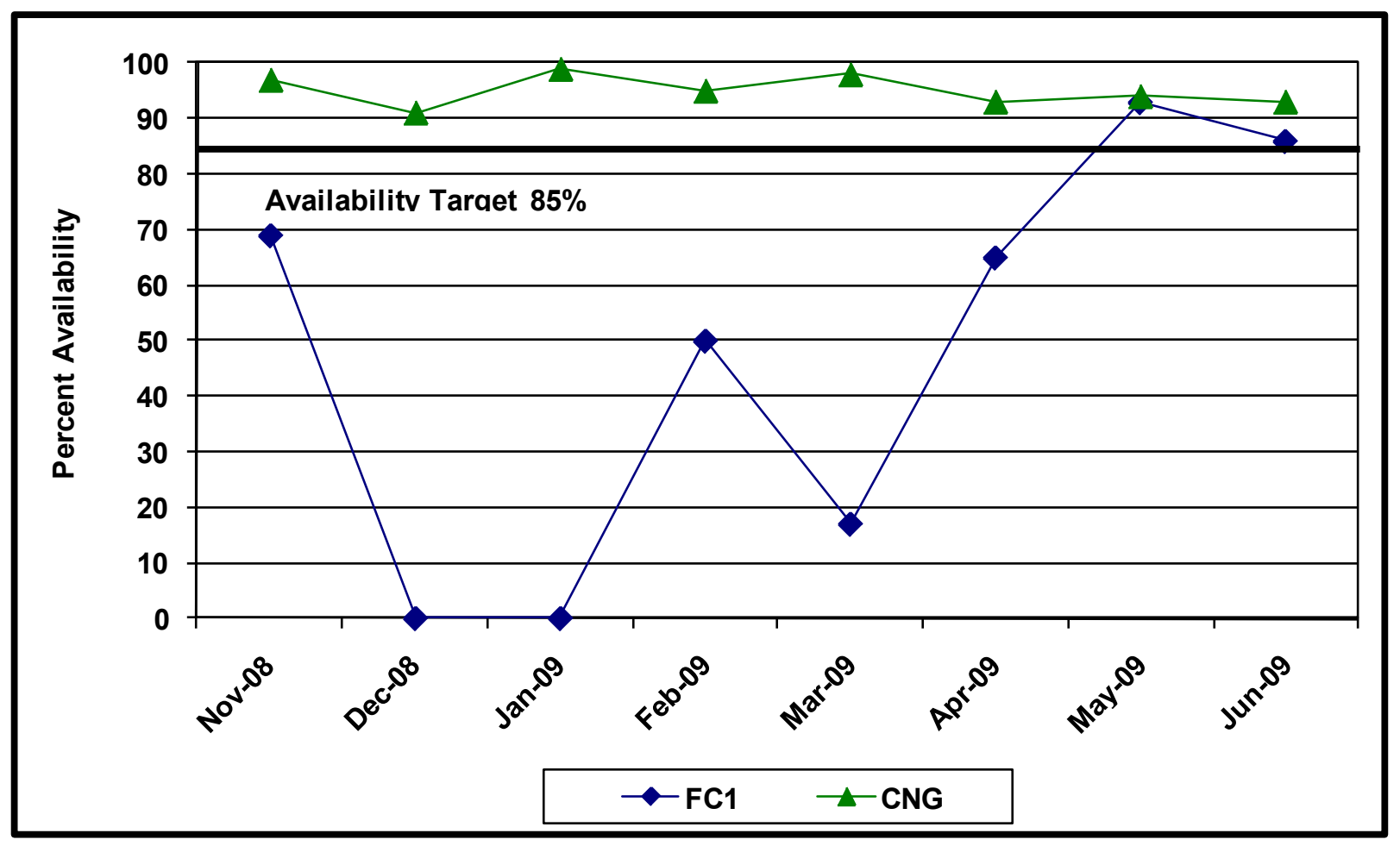

Figure 7. Availability for study bus groups

The chart shows that the CNG buses have consistently achieved availability above the $85 \%$ target. This is typical for new buses in service.

Table 2 provides a summary of the availability and unavailability reasons for each of the study bus groups. Overall, during the evaluation period, the average availability for the fuel cell bus was $51 \%$, and availability for the CNG buses was $95 \%$. As discussed, the primary issues that kept the fuel cell bus out of service were downtime for traction battery replacement $(64 \%)$ and fueling station unavailability (26\%). Issues with the fuel cell system accounted for only $7 \%$ of the unavailability. Issues that kept the $\mathrm{CNG}$ buses out of service were general maintenance. 
Table 2. Summary of Reasons for Availability and Unavailability of Buses for Service

\begin{tabular}{|l|c|c|c|c|}
\hline \multirow{2}{*}{ Category } & \multicolumn{2}{c|}{ Fuel Cell Bus } & \multicolumn{2}{c|}{ CNG Buses } \\
\cline { 2 - 5 } & Number & Percent & Number & Percent \\
\hline Planned Work Days & 197 & & 1,097 & \\
\hline Days Available & 101 & 51 & 1,043 & 95 \\
\hline Available & $\mathbf{1 0 1}$ & $\mathbf{1 0 0}$ & $\mathbf{1 , 0 4 3}$ & $\mathbf{1 0 0}$ \\
\hline On-Route & 98 & 97 & 988 & 95 \\
\hline Event/Demonstration & 3 & 3 & 1 & 0 \\
\hline Training & 0 & 0 & 3 & 0 \\
\hline Not Used & 0 & 0 & 51 & 5 \\
\hline Unavailable & $\mathbf{9 6}$ & $\mathbf{1 0 0}$ & $\mathbf{5 4}$ & $\mathbf{1 0 0}$ \\
\hline Fuel Cell Propulsion & 7 & 7 & & \\
\hline ISE Propulsion & 0 & 0 & & \\
\hline Traction Batteries & 61 & 64 & & \\
\hline SunLine Maintenance & 3 & 3 & 54 & 100 \\
\hline Fueling Unavailable & 25 & 26 & & \\
\hline
\end{tabular}

\section{Fuel Economy and Cost}

Table 3 shows hydrogen and CNG fuel consumption and fuel economy for the study bus groups during the evaluation period. Using the GGE fuel economy and the CNG buses as the baseline, the fuel cell bus had a fuel economy more than two times higher than the CNG buses. Figure 8 shows average fuel economies for each of the study bus groups. It is interesting to note that these newer CNG buses have a fuel economy $8 \%$ higher than the previous group of baseline buses. The new buses are equipped with engines that meet 2010 emissions regulations using stoichiometric cooled exhaust gas recirculation combustion with a three-way catalyst.

The fuel costs per mile for the study bus groups for the evaluation period were $\$ 1.12$ per mile for the fuel cell bus and $\$ 0.31$ for the CNG buses. The fuel cost for CNG has been much lower than the cost for hydrogen production.

Table 3. Fuel Use and Economy (Evaluation Period)

\begin{tabular}{|c|c|c|c|c|c|}
\hline Bus & $\begin{array}{c}\text { Mileage } \\
\text { (Fuel Base) }\end{array}$ & $\begin{array}{c}\text { Hydrogen (kg) } \\
\text { or CNG (GGE) }\end{array}$ & $\begin{array}{c}\text { Miles per } \\
\text { kg or GGE }\end{array}$ & $\begin{array}{c}\text { Diesel Equivalent } \\
\text { Amount (Gallon) }\end{array}$ & $\begin{array}{c}\text { Miles per } \\
\text { Gallon (DGE) }\end{array}$ \\
\hline FC1 & $\mathbf{1 2 , 5 2 9}$ & $\mathbf{1 , 7 5 5 . 9}$ & $\mathbf{7 . 1 4}$ & $\mathbf{1 , 5 5 3 . 9}$ & $\mathbf{8 . 0 6}$ \\
\hline 603 CNG & 44,046 & $12,668.8$ & 3.48 & $11,338.6$ & 3.88 \\
\hline 604 CNG & 37,209 & $11,100.6$ & 3.35 & $9,935.0$ & 3.75 \\
\hline 605 CNG & 38,186 & $11,457.4$ & 3.33 & $10,254.4$ & 3.72 \\
\hline 606 CNG & 41,423 & $12,359.5$ & 3.35 & $11,061.7$ & 3.74 \\
\hline 608 CNG & 38,126 & $11,075.0$ & 3.44 & $9,912.1$ & 3.85 \\
\hline CNG Total & $\mathbf{1 9 8 , 9 9 0}$ & $\mathbf{5 8 , 6 6 1 . 2}$ & $\mathbf{3 . 3 9}$ & $\mathbf{5 2 , 5 0 1 . 8}$ & $\mathbf{3 . 7 9}$ \\
\hline
\end{tabular}




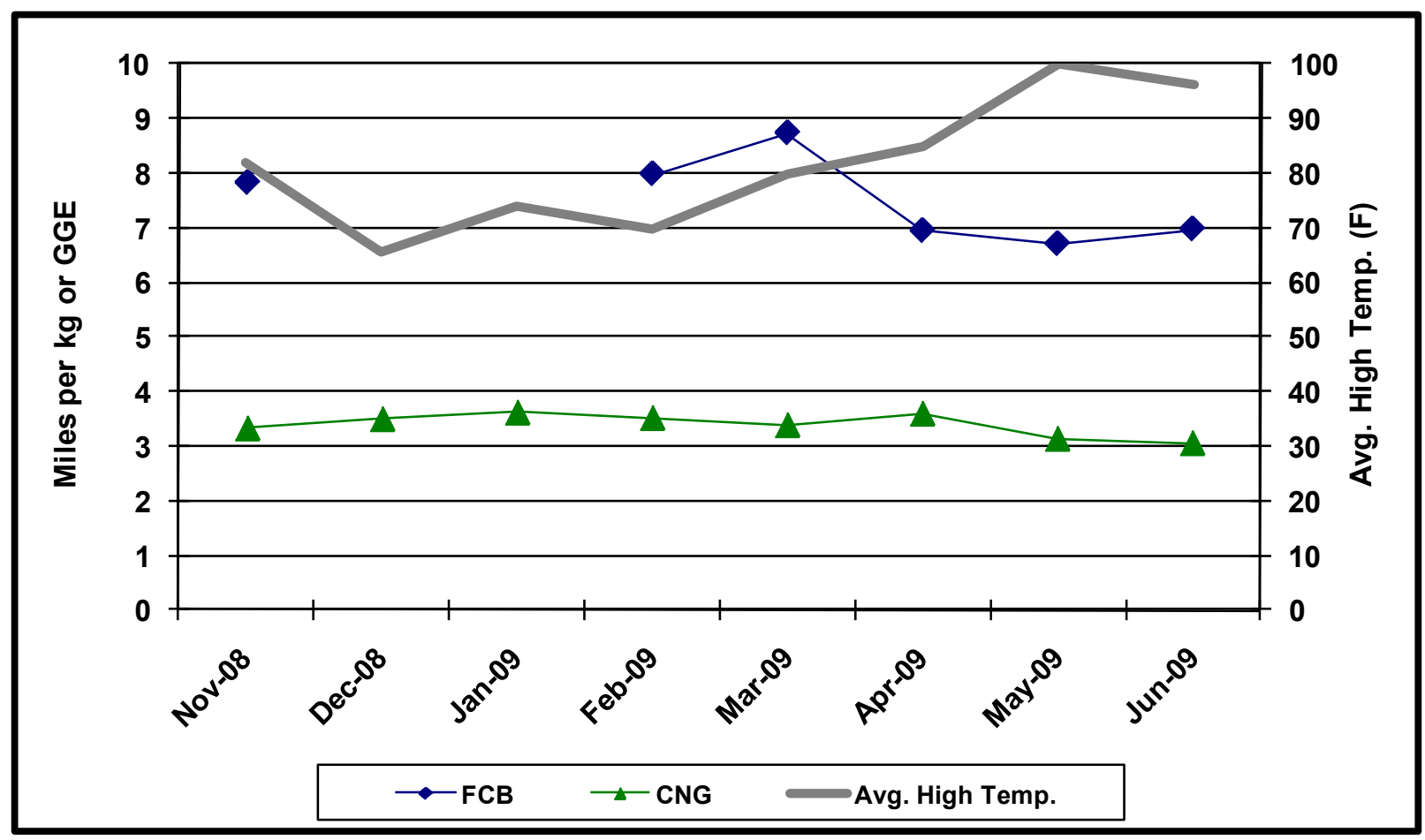

Figure 8. Average fuel economy (miles per kg or GGE)

\section{Maintenance Analysis}

The maintenance cost analysis in this section is only for the evaluation period. Warranty costs are generally not included in the cost-per-mile calculations. All work orders for the study buses were collected and analyzed for this evaluation. For consistency, we set the maintenance labor rate at $\$ 50$ per hour, which does not reflect an average rate for SunLine. This section covers total maintenance costs first and then maintenance costs separated by bus system.

Total Maintenance Costs - Total maintenance costs include the price of parts and hourly labor rates of $\$ 50$ per hour. Cost per mile is calculated as follows:

$$
\text { Cost per mile }=[(\text { labor hours } * 50)+\text { parts cost }] / \text { mileage }
$$

Table 4 shows total maintenance costs for the fuel cell bus and CNG buses. The CNG buses have total maintenance costs $39 \%$ lower than the fuel cell bus. The parts costs are low for the fuel cell bus because they are typically covered by the manufacturers for most of the propulsion system maintenance; however, SunLine's mechanics do most of the work. CNG bus number 603 had higher maintenance costs because of body damage and issues with the air-conditioning system. 
Table 4. Total Maintenance Costs (Evaluation Period)

\begin{tabular}{|c|c|c|c|c|}
\hline Bus & Mileage & Parts (\$) & $\begin{array}{c}\text { Labor } \\
\text { Hours }\end{array}$ & $\begin{array}{c}\text { Cost (\$) } \\
\text { per Mile }\end{array}$ \\
\hline Fuel Cell & $\mathbf{1 2 , 5 2 9}$ & $\mathbf{1 , 2 7 5 . 3 6}$ & $\mathbf{8 2 . 5}$ & $\mathbf{0 . 4 3}$ \\
\hline 603 CNG & 44,046 & $3,328.78$ & 171.0 & 0.27 \\
\hline 604 CNG & 37,209 & $2,153.93$ & 163.0 & 0.28 \\
\hline 605 CNG & 38,186 & $2,438.45$ & 148.3 & 0.26 \\
\hline 606 CNG & 41,423 & $2,427.51$ & 145.5 & 0.23 \\
\hline 608 CNG & 38,126 & $1,518.92$ & 136.6 & 0.22 \\
\hline Total CNG & $\mathbf{1 9 8 , 9 9 0}$ & $\mathbf{1 1 , 8 6 7 . 5 9}$ & $\mathbf{7 6 4 . 6}$ & $\mathbf{0 . 2 5}$ \\
\hline
\end{tabular}

Maintenance Costs Separated by System - Table 5 shows maintenance costs by vehicle system and bus study group (without warranty costs included). The vehicle systems shown in the table include the following:

- Cab, Body, and Accessories: Includes body, glass, and paint repairs following accidents; cab and sheet metal repairs on seats and doors; and accessory repairs such as hubodometers and radios.

- Propulsion-Related Systems: Repairs for exhaust, fuel, engine, electric motors, fuel cell modules, propulsion control, non-lighting electrical (charging, cranking, and ignition), air intake, cooling, and transmission.

- Preventive Maintenance Inspections (PMI): Labor for inspections during preventive maintenance.

- Brakes

- Frame, Steering, and Suspension

- Heating, Ventilation, and Air Conditioning (HVAC)

- Lighting

- Air System, General

- Axles, Wheels, and Drive Shaft

- Tires

For the fuel cell bus, the systems with the highest percentage of maintenance costs were propulsion-related, cab, body, and accessories, and PMI. The propulsion-related maintenance was significantly more than for the CNG buses; however, the PMI and cab, body, and accessories categories were essentially the same as for the CNG buses. For the CNG buses, the highest percentage of maintenance costs were cab, body, and accessories, PMI, and propulsionrelated. 
Table 5. Vehicle System Maintenance Cost per Mile by System (Evaluation Period)

\begin{tabular}{|l|c|c|c|c|}
\hline \multirow{2}{*}{ System } & \multicolumn{2}{c|}{ Fuel Cell } & \multicolumn{2}{c|}{ CNG } \\
\cline { 2 - 5 } & $\begin{array}{c}\text { Cost per } \\
\text { Mile (\$) }\end{array}$ & $\begin{array}{c}\text { Percent of } \\
\text { Total (\%) }\end{array}$ & $\begin{array}{c}\text { Cost per } \\
\text { Mile (\$) }\end{array}$ & $\begin{array}{c}\text { Percent of } \\
\text { Total (\%) }\end{array}$ \\
\hline Cab, Body, and Accessories & 0.08 & 18 & 0.10 & 39 \\
\hline Propulsion-Related & 0.16 & 37 & 0.05 & 20 \\
\hline PMI & 0.06 & 14 & 0.07 & 29 \\
\hline Brakes & 0.00 & 0 & 0.00 & 0 \\
\hline Frame, Steering, and Suspension & 0.03 & 7 & 0.00 & 1 \\
\hline HVAC & 0.00 & 1 & 0.01 & 5 \\
\hline Lighting & 0.06 & 14 & 0.00 & 2 \\
\hline Axles, Wheels, and Drive Shaft & 0.00 & 0 & 0.00 & 0 \\
\hline General Air System Repairs & 0.02 & 4 & 0.00 & 1 \\
\hline Tires & 0.02 & 4 & 0.01 & 4 \\
\hline Total & $\mathbf{0 . 4 3}$ & $\mathbf{1 0 0}$ & $\mathbf{0 . 2 5}$ & $\mathbf{1 0 0}$ \\
\hline
\end{tabular}

Propulsion-Related Maintenance Costs - The propulsion-related vehicle systems include the exhaust, fuel, engine, electric propulsion, air intake, cooling, non-lighting electrical, and transmission systems. Table 6 categorizes the propulsion-related system repairs for the study bus groups during the evaluation period (no warranty). Each of the study bus groups was under warranty during the entire evaluation period. Also, the fuel cell bus was maintained by the UTC Power engineer when the fuel cell power system required significant repairs. During the evaluation period of this report, the SunLine mechanics did much of the maintenance on the fuel cell bus themselves supported by the manufacturers; however, as mentioned above, the manufacturers generally supplied the parts under warranty for the propulsion system, so the costs for these parts are not included.

- Total propulsion-related - The fuel cell bus had more than double the maintenance cost for propulsion-related maintenance compared with the CNG buses. The majority of this maintenance for the fuel cell bus has been labor.

- Exhaust System - There were few or no costs for this system for the study bus groups.

- Fuel System - Costs for the fuel system were low for both bus groups.

- Powerplant and electric propulsion - The fuel cell bus maintenance reported here involved almost exclusively SunLine mechanics supporting manufacturer work on the bus. The preventive maintenance for the CNG buses was almost exclusively in the powerplant category (and none for electric propulsion).

- Non-lighting electrical (charging, cranking, and ignition) - The fuel cell bus had some minor costs in this category relating to 24 -volt batteries. The $\mathrm{CNG}$ buses mostly had preventive maintenance repairs in this category for spark plugs at the 24,000 -preventivemaintenance cycle for each bus. 
Table 6. Propulsion-Related Maintenance Costs by System (Evaluation Period)

\begin{tabular}{|c|c|c|}
\hline Maintenance System Costs & Fuel Cell & CNG \\
\hline Mileage & 12,529 & 198,990 \\
\hline \multicolumn{3}{|c|}{ Total Propulsion-Related Systems (Roll-up) } \\
\hline Parts cost (\$) & 8.27 & $5,420.12$ \\
\hline Labor hours & 40.3 & 90.5 \\
\hline Total cost $(\$)$ & $2,020.77$ & $9,945.12$ \\
\hline Total cost (\$) per mile & 0.16 & 0.05 \\
\hline \multicolumn{3}{|l|}{ Exhaust System Repairs } \\
\hline Parts cost $(\$)$ & 0.00 & 0.00 \\
\hline Labor hours & 0.0 & 0.0 \\
\hline Total cost $(\$)$ & 0.00 & 0.00 \\
\hline Total cost (\$) per mile & 0.00 & 0.00 \\
\hline \multicolumn{3}{|l|}{ Fuel System Repairs } \\
\hline Parts cost $(\$)$ & 0.00 & 183.30 \\
\hline Labor hours & 0.0 & 3.5 \\
\hline Total cost $(\$)$ & 0.00 & 358.30 \\
\hline Total cost (\$) per mile & 0.00 & 0.00 \\
\hline \multicolumn{3}{|l|}{ Powerplant System Repairs } \\
\hline Parts cost $(\$)$ & 5.84 & $3,021.47$ \\
\hline Labor hours & 15.8 & 74.3 \\
\hline Total cost $(\$)$ & 793.34 & $6,733.97$ \\
\hline Total cost (\$) per mile & 0.06 & 0.03 \\
\hline \multicolumn{3}{|l|}{ Electric Propulsion System Repairs } \\
\hline Parts cost $(\$)$ & 0.00 & 0.00 \\
\hline Labor hours & 23.5 & 0.0 \\
\hline Total cost $(\$)$ & $1,175.00$ & 0.00 \\
\hline Total cost (\$) per mile & 0.09 & 0.00 \\
\hline \multicolumn{3}{|c|}{$\begin{array}{l}\text { Non-Lighting Electrical System Repairs (General Electrical, Charging, } \\
\text { Cranking, Ignition) }\end{array}$} \\
\hline Parts cost $(\$)$ & 2.43 & $1,674.85$ \\
\hline Labor hours & 1.0 & 5.3 \\
\hline Total cost $(\$)$ & 52.43 & $1,937.35$ \\
\hline Total cost (\$) per mile & 0.00 & 0.01 \\
\hline \multicolumn{3}{|l|}{ Air Intake System Repairs } \\
\hline Parts cost $(\$)$ & 0.00 & 268.73 \\
\hline Labor hours & 0.0 & 0.0 \\
\hline Total cost $(\$)$ & 0.00 & 268.73 \\
\hline Total cost (\$) per mile & 0.00 & 0.00 \\
\hline \multicolumn{3}{|l|}{ Cooling System Repairs } \\
\hline Parts cost $(\$)$ & 0.00 & 0.00 \\
\hline Labor hours & 0.0 & 3.5 \\
\hline Total cost $(\$)$ & 0.00 & 175.00 \\
\hline Total cost (\$) per mile & 0.00 & 0.00 \\
\hline \multicolumn{3}{|l|}{ Transmission System Repairs } \\
\hline Parts cost $(\$)$ & 0.00 & 97.92 \\
\hline Labor hours & 0.0 & 1.5 \\
\hline Total cost $(\$)$ & 0.00 & 172.92 \\
\hline Total cost (\$) per mile & 0.00 & 0.00 \\
\hline
\end{tabular}


- Air intake - The fuel cell bus had no costs in this category, and the CNG buses had only air filter changeouts.

- Cooling - The fuel cell and CNG buses had low or no costs in this category. .

- Transmission - Only the CNG buses had costs in this category for filters under preventive maintenance.

\section{Roadcall Analysis}

A roadcall (RC), or revenue vehicle system failure (as named in the National Transit Database ${ }^{9}$ ), is defined as a failure of an in-service bus that causes the bus to be replaced on route or causes a significant delay in schedule. If the problem with the bus can be repaired during a layover and the bus remains on schedule, this is not considered a RC. The analysis provided here includes only RCs caused by "chargeable" failures. Chargeable RCs include systems that can physically disable the bus from operating on route, such as interlocks (doors and wheelchair lift) and engine problems. Chargeable RCs do not include RCs for things such as radios or destination signs.

Table 7 shows the RCs and miles between roadcalls (MBRC) for each study bus in two categories: all RCs and propulsion-related-only RCs. The fuel cell bus had several RCs and low vehicle use, which indicates the prototype nature of the technology. For the fuel cell bus, the four propulsion RCs were caused by the fuel cell system ( $3 \mathrm{RCs}$ ) and traction batteries (1 RC). The CNG buses had propulsion RCs for the engine (2 RCs), electrical (1 RC), and hydraulic leak (1 RC).

Table 7. Roadcalls and MBRC (Evaluation Period)

\begin{tabular}{|l|c|c|c|c|c|}
\hline \multicolumn{1}{|c|}{ Bus } & Mileage & $\begin{array}{c}\text { All } \\
\text { Roadcalls }\end{array}$ & All MBRC & $\begin{array}{c}\text { Propulsion } \\
\text { Roadcalls }\end{array}$ & $\begin{array}{c}\text { Propulsion } \\
\text { MBRC }\end{array}$ \\
\hline Fuel Cell & $\mathbf{1 2 , 5 2 9}$ & $\mathbf{5}$ & $\mathbf{2 , 5 0 6}$ & $\mathbf{4}$ & $\mathbf{3 , 1 3 2}$ \\
\hline 603 CNG & 44,046 & 1 & 44,046 & 1 & 44,046 \\
\hline 604 CNG & 37,209 & 3 & 12,403 & 1 & 37,209 \\
\hline 605 CNG & 38,186 & 4 & 9,546 & 2 & 19,093 \\
\hline 606 CNG & 41,423 & 0 & & 0 & \\
\hline 608 CNG & 38,126 & 2 & 19,063 & 0 & \\
\hline Total CNG & $\mathbf{1 9 8 , 9 9 0}$ & $\mathbf{1 0}$ & $\mathbf{1 9 , 8 9 9}$ & $\mathbf{4}$ & $\mathbf{4 9 , 7 4 8}$ \\
\hline
\end{tabular}

\footnotetext{
${ }^{9}$ Federal Transit Administration's National Transit Database Web site: www.ntdprogram.gov/ntdprogram/
} 


\section{Demonstration Achievements and Challenges}

SunLine and its project partners have gained valuable experience from operating the fuel cell bus. This section provides a summary of the achievements and challenges encountered during the demonstration.

\section{Achievements}

SunLine's original goal was to demonstrate this prototype 40-foot fuel cell bus in regular revenue service for at least two years, aiding the manufacturers and the industry in testing and investigating what modifications were required to commercialize the technology for transit. Testing at SunLine's location also provides an opportunity to evaluate how the technology operates in a hot, desert climate. Since that time, the agency has operated the bus for three and a half years, providing an excellent opportunity for the manufacturers to learn how the bus performs in real service and to optimize the system further to increase reliability and durability.

- Bus Operation - The fuel cell bus went into service in January 2006. Through June 2009 , the bus had operated over 79,000 miles and accumulated 5,820 hours on the fuel cell system. This process has been extremely important to help the manufacturers determine the potential weak points in the system and make modifications to optimize and improve the design for the next generation of systems.

- Fuel Economy - SunLine's fuel cell bus achieved an average fuel economy of 7.2 miles per kg. This equates to 8.14 miles per diesel gallon equivalent, which is more than two times that of a typical diesel bus average of around 4 miles per gallon. SunLine's newest conventional CNG buses average 3.79 miles per diesel gallon equivalent. Fuel economy for buses in transit service is highly dependent on the duty-cycle; however, this achievement meets the NFCBP performance target of doubling the fuel efficiency over conventional transit buses ${ }^{10}$.

- Hydrogen Fueling - SunLine has operated a variety of hydrogen production and fueling technologies safely since 2000. During this demonstration, the agency had a commercial natural gas reformer installed and upgraded the station to increase storage capacity. Since January 2006, SunLine has dispensed over $26,000 \mathrm{~kg}$ of hydrogen into its two hydrogen-fueled buses (including the HHICE bus) with no major safety incidents. The dispenser has an average fueling rate of around $1.0 \mathrm{~kg}$ per minute, and fill times take less than 20 minutes.

- Training - SunLine's maintenance staff have been trained to accomplish much of the work on the fuel cell bus; although, the fuel cell manufacturer still does most of the major maintenance on the fuel cell system. Agency staff assists the UTC Power engineer with the fuel cell system repairs and now handle the majority of the repairs of the hybrid system. This is a major step toward a goal of transferring all maintenance to agency staff.

- Public Awareness - SunLine has increased public awareness of hydrogen and fuel cell technology through its demonstration. The agency operates the bus as much as possible on two of its most visible routes and participates in many events in the area.

\footnotetext{
${ }^{10}$ FTA NFCBP Solicitation Guidelines: www.fta.dot.gov/documents/Fuel_Cell_Solicitation_Guidelines_Final.doc
} 


\section{Challenges}

The primary challenges for operating prototype fuel cell bus technology in a transit application are cost and reliability/durability. SunLine and its partners have worked closely to address the specific issues encountered and have made much progress in further developing the technology.

- Costs - Fuel cell buses are following the typical trend as all prototype technology: capital costs are high in the early stages and begin to fall with increased production and further product development. The operating costs are also higher than that of conventional technology.

- Fuel cell bus reliability/durability - The manufacturers are working with SunLine to increase the reliability and durability of fuel cell buses to meet transit requirements. Several issues were encountered during the demonstration primarily with the traction batteries and the fuel cell system. These issues were also encountered at the other demonstration sites for this bus.

- Traction Battery Issues - Management of the ZEBRA batteries in this design has proved to be the biggest challenge. The hybrid design on the bus includes three traction batteries operating in parallel. A cell in a ZEBRA battery typically will fail in short circuit. A battery with failed cells has reduced voltage even though it still can be operated. Because the batteries operate with a direct parallel connection, when the number of failed cells within each of the batteries is too different among the three batteries, the difference causes an unbalancing of the state of charge (SOC). This imbalance makes it difficult to keep the batteries in the recommended operating range. The present SOC balancing algorithm will disconnect a battery temporarily to keep the SOC balanced.

This situation may mislead over-volt errors in the propulsion system, causing a bus shutdown. UTC Power has been working closely with the battery manufacturer (MES-DEA) on the issue for some time. Because failed cells are related to a stress condition due to the battery use, some progress has been made with controller software changes to improve battery operation by refining some operational limits. Options for a balancing strategy are under discussion. More replacement batteries are kept in stock to increase the number of available bettermatched batteries and to reduce the amount of downtime of the fuel cell bus.

- Fuel Cell System Issues - UTC Power monitors the performance of the fuel cell power system to analyze actual performance versus predicted performance. Early on in the demonstration, the cell stack assemblies (CSAs) showed power degradation in the operation of the bus. When the power degradation of the CSAs falls below $90 \mathrm{~kW}$ to $100 \mathrm{~kW}$ of the original $120 \mathrm{~kW}$, the system is considered to be at the end of its life and should be replaced. This early power degradation was reported with the fuel cell buses at other agencies as well, and UTC Power reports the problem as an issue of contamination within the CSAs causing the premature degradation beyond end of life (at about 800 to 1,200 hours of operation instead of the expected 4,000 hours or more). A new version of CSAs replaced the CSAs on the SunLine fuel cell bus on April 15-16, 2008. UTC Power reported that this 
early power-degradation issue was resolved for these buses, and the results in this evaluation report support that assertion.

\section{What's Next for SunLine?}

This report covers SunLine's operation of the fuel cell and CNG buses from April 2008 through June 2009. This is the last planned evaluation report on this bus design. Future reports will focus on the newer technology being introduced.

American Fuel Cell Bus Project: Funded under the FTA's National Fuel Cell Bus Program, SunLine is leading a team to develop a purpose-built fuel cell bus that meets "Buy America" requirements. The design features a number of advancements that are expected to result in a highly efficient bus. Elements include advanced energy storage and new power electronics, high-efficiency accessories, and the newest-generation fuel cell on a U.S.-built chassis.

Advanced Fuel Cell Bus Project: SunLine plans to demonstrate another fuel cell bus under funding from CARB, AQMD, and FTA. This project is currently in the planning stage and will be announced once negotiations with the partners are complete.

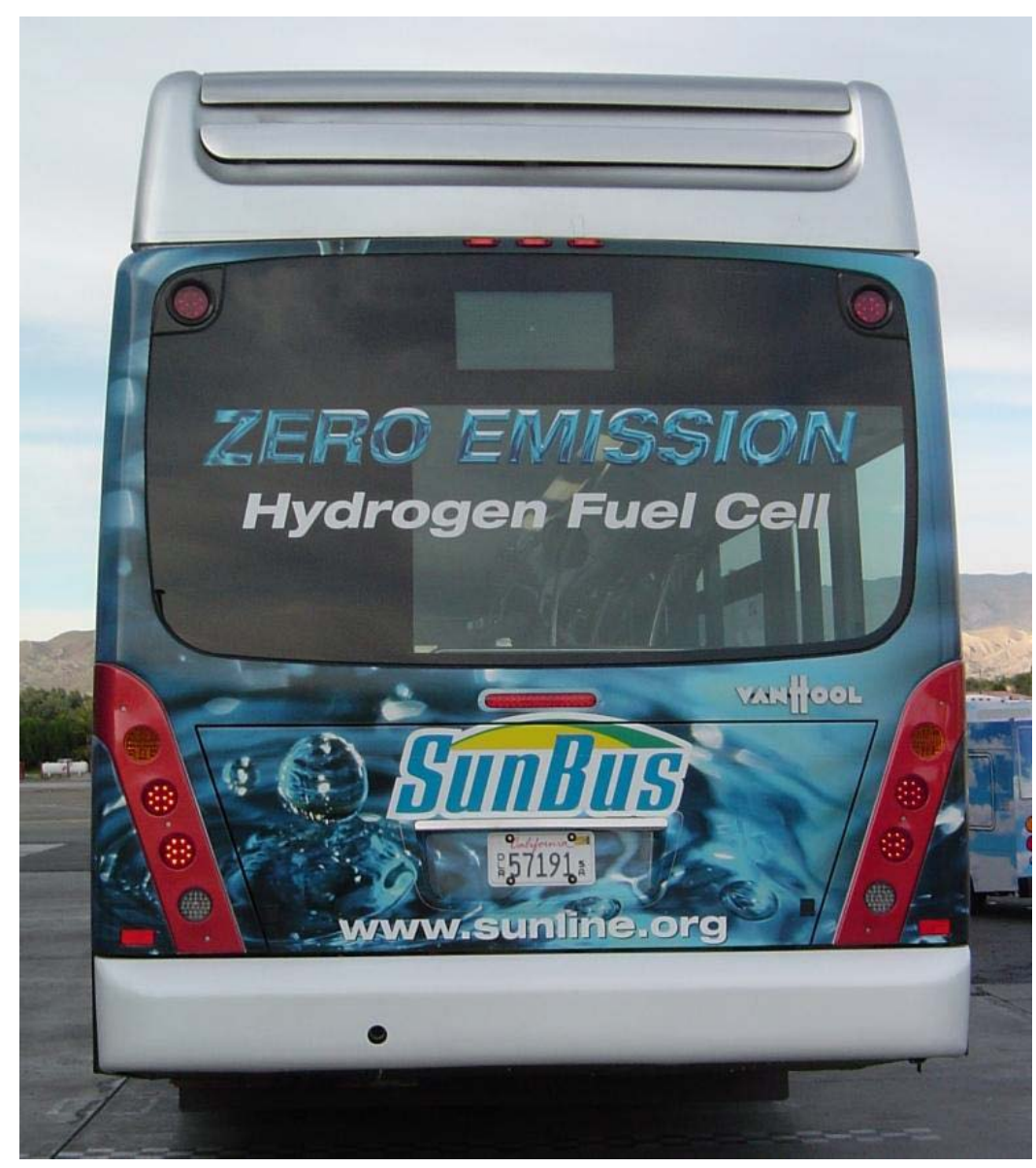




\section{Contacts}

DOE

1000 Independence Ave., SW

Washington, DC 20585

John Garbak, Technology Validation

Manager, Vehicle Technologies Program

Phone: 202-586-1723

E-mail: john.garbak@ee.doe.gov

\section{NREL}

1617 Cole Boulevard

Golden, CO 80401

Leslie Eudy, Senior Project Leader

Phone: 303-275-4412

E-mail: leslie eudy@nrel.gov

\section{Battelle}

505 King Avenue

Columbus, $\mathrm{OH} 43201$

Kevin Chandler, Program Manager

Phone: 614-424-5127

E-mail: chandlek@,battelle.org

\section{SunLine}

32-505 Harry Oliver Trail

Thousand Palms, CA 92276

Tommy Edwards, Director of Maintenance

Phone: 760-343-3456

E-mail: tedwards@sunline.org

\section{UTC Power}

195 Governor's Highway

South Windsor, CT 06074

Rakesh Radhakrishnan,

Program Manager, Transportation Programs

Phone: 860-727-2754

E-mail: rakeshr@utcpower.com
Matthew Riley, Systems Engineer

Phone: 860-727-2864

E-mail: Matthew.Riley@utcpower.com

ISE Corporation

12302 Kerran Street

Poway, CA 92064

Paul Scott, Chief Scientific Officer

Phone: 858-413-1742

E-mail: pscott@isecorp.com

HyRadix

175 West Oakton Street

Des Plaines, IL 60018

Terry Schuster, Director of Sales

Phone: 630-416-7425

E-mail: terry.schuster@hyradix.com

Van Hool

Bernard Van Hoolstraat 58

B-2500 Lier Koningshooikt

Belgium

Paul Jenné, Automotive Relations

Phone: +32 (3) 4202210

E-mail: paul.jenne@,vanhool.be 


\section{References and Related Reports}

All NREL hydrogen and fuel cell-related evaluation reports can be downloaded from the following Web site: www.nrel.gov/hydrogen/proj_fc bus_eval.html.

\section{SunLine}

Chandler, K.; Eudy, L. SunLine Transit Agency, Fuel Cell Transit Bus: Fourth Evaluation Report and Appendices. NREL/TP-560-44646-1, NREL/TP-560-44646-2. Golden, CO: National Renewable Energy Laboratory, 2009.

NREL. SunLine Begins Extended Testing of Hybrid Fuel Cell Bus. DOE/GO12008-2610. Golden, CO: National Renewable Energy Laboratory, 2008.

Chandler, K.; Eudy, L. SunLine Transit Agency, Hydrogen-Powered Transit Buses: Third Evaluation Report and Appendices. NREL/TP-560-43741-1, NREL/TP-560-43741-2. Golden, CO: National Renewable Energy Laboratory, 2008.

Chandler, K.; Eudy, L. SunLine Transit Agency, Hydrogen-Powered Transit Buses: Evaluation Results Update. NREL/TP-560-42080. Golden, CO: National Renewable Energy Laboratory, 2007.

Chandler, K.; Eudy, L. SunLine Transit Agency, Hydrogen-Powered Transit Buses: Preliminary Evaluation Results. NREL/TP-560-41001. Golden, CO: National Renewable Energy Laboratory, 2007.

NREL. SunLine Expands Horizons with Fuel Cell Bus Demo. DOE/GO-102006-2287. Golden, CO: National Renewable Energy Laboratory, 2006.

NREL. SunLine Tests HHICE Bus in Desert Climate. DOE/GO-102006-2333. Golden, CO: National Renewable Energy Laboratory, 2006.

Chandler, K. Ten Years of Compressed Natural Gas (CNG) Operations at SunLine Transit Agency. NREL/SR-540-39180. Golden, CO: National Renewable Energy Laboratory, 2006.

Chandler, K.; Eudy, L. ThunderPower Bus Evaluation at SunLine Transit Agency. DOE/GO102003-1786. Golden, CO: National Renewable Energy Laboratory, 2003.

NREL. SunLine Test Drives Hydrogen Bus. DOE/GO-102003-1768. Golden, CO: National Renewable Energy Laboratory, 2003.

\section{General}

Eudy, L.; Chandler, K.; Gikakis, C. Fuel Cell Buses in U.S. Transit Fleets: Current Status 2008. NREL/TP-560-44133. Golden, CO: National Renewable Energy Laboratory, 2008.

NREL. Hydrogen and Fuel Cell Transit Bus Evaluations: Joint Evaluation Plan for the U.S. Department of Energy and the Federal Transit Administration. NREL/MP-560-42781. Golden, CO: National Renewable Energy Laboratory, 2008. 
Eudy, L.; Chandler, K.; Gikakis, C. Fuel Cell Buses in U.S. Transit Fleets: Summary of Experiences and Current Status. NREL/TP-560-41967. Golden, CO: National Renewable Energy Laboratory, 2007.

\section{AC Transit}

Chandler, K.; Eudy, L. National Fuel Cell Bus Program: Accelerated Testing Evaluation Report and Appendices. FTA-CO-26-7004-2009.1, FTA-CO-26-7004-2009.1A. Golden, CO: National Renewable Energy Laboratory, 2009.

Chandler, K.; Eudy, L. Alameda-Contra Costa Transit District (AC Transit), Fuel Cell Transit Buses: Third Evaluation Report and Appendices. NREL/TP-560-43545-1, NREL/TP-560-435452. Golden, CO: National Renewable Energy Laboratory, 2008.

Chandler, K.; Eudy, L. Alameda-Contra Costa Transit District (AC Transit), Fuel Cell Transit Buses: Third Evaluation Report and Appendices. NREL/TP-560-43545-1, NREL/TP-560-435452. Golden, CO: National Renewable Energy Laboratory, 2008.

Chandler, K.; Eudy, L. Alameda-Contra Costa Transit District (AC Transit), Fuel Cell Transit Buses: Evaluation Results Update. NREL/TP-560-42249. Golden, CO: National Renewable Energy Laboratory, 2007.

Chandler, K.; Eudy, L. AC Transit, Fuel Cell Transit Buses: Preliminary Evaluation Results. NREL/TP-560-41041. Golden, CO: National Renewable Energy Laboratory, 2007.

NREL. AC Transit Demos Three Prototype Fuel Cell Buses. DOE/GO-102006-2286. Golden, CO: National Renewable Energy Laboratory, 2006.

\section{Connecticut Transit}

Chandler, K.; Eudy, L. Connecticut Transit (CTTRANSIT) Fuel Cell Transit Bus: Second Evaluation Report and Appendices. NREL/TP-560-45670-1, NREL/TP-560-45670-2. Golden, CO: National Renewable Energy Laboratory, 2009.

Chandler, K., Eudy, L. Connecticut Transit (CTTRANSIT) Fuel Cell Transit Bus: Preliminary Evaluation Results. NREL/TP-560-43847. Golden, CO: National Renewable Energy Laboratory, 2008.

NREL. CTTRANSIT Operates New England's First Fuel Cell Hybrid Bus. DOE/GO12008-2529. Golden, CO: National Renewable Energy Laboratory, 2008.

\section{Santa Clara Valley Transportation Authority}

Chandler, K.; Eudy, L. Santa Clara Valley Transportation Authority and San Mateo County Transit District, Fuel Cell Transit Buses: Evaluation Results. NREL/TP-560-40615. Golden, CO: National Renewable Energy Laboratory, 2006.

NREL. VTA. SamTrans Look into Future with Bus Demo. DOE/GO-102005-2147. Golden, CO: National Renewable Energy Laboratory, 2005. 


\section{REPORT DOCUMENTATION PAGE}

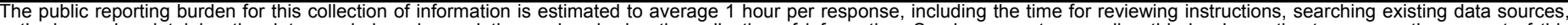

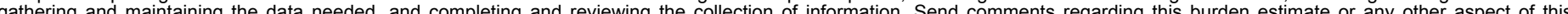

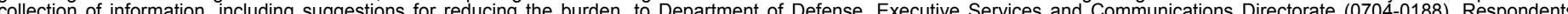

chould be aware that notwithstanding any other provision of law, no person shall be subject to any penalty

should be aware that notwithstanding

PLEASE DO NOT RETURN YOUR FORM TO THE ABOVE ORGANIZATION.

\section{REPORT DATE (DD-MM-YYYY) August 2009}

4. TITLE AND SUBTITLE

SunLine Transit Agency Fuel Cell Transit Bus:

Fifth Evaluation Report (Report and Appendices)
3. DATES COVERED (From - To) August 2009

5a. CONTRACT NUMBER

DE-AC36-08-GO28308

5b. GRANT NUMBER

5c. PROGRAM ELEMENT NUMBER

5d. PROJECT NUMBER

NREL/TP-560-46346

5e. TASK NUMBER

FC087820

5f. WORK UNIT NUMBER
7. PERFORMING ORGANIZATION NAME(S) AND ADDRESS(ES)

National Renewable Energy Laboratory

1617 Cole Blvd.

Golden, CO 80401-3393
8. PERFORMING ORGANIZATION REPORT NUMBER

NREL/TP-560-46346

9. SPONSORING/MONITORING AGENCY NAME(S) AND ADDRESS(ES)

10. SPONSOR/MONITOR'S ACRONYM(S) NREL

11. SPONSORING/MONITORING AGENCY REPORT NUMBER

12. DISTRIBUTION AVAILABILITY STATEMENT

National Technical Information Service

U.S. Department of Commerce

5285 Port Royal Road

Springfield, VA 22161

13. SUPPLEMENTARY NOTES

14. ABSTRACT (Maximum 200 Words)

This report describes operations at SunLine Transit Agency for a prototype fuel cell bus and five compressed natural gas (CNG) buses. This is the fifth evaluation report for this site, and it describes results and experiences from October 2008 through June 2009. These results are an addition to those provided in the previous four evaluation reports.

\section{SUBJECT TERMS}

SunLine Transit Agency; fuel cell; transit bus; compressed natural gas; CNG

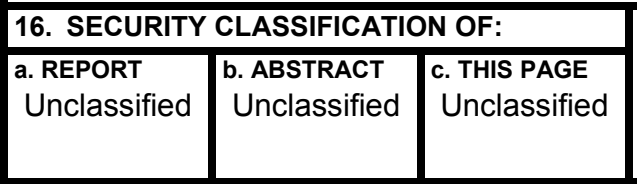

\begin{tabular}{l|l|} 
17. & LIMITATION \\
OF ABSTRACT & $\begin{array}{l}\text { 18. } \\
\text { NUMBER } \\
\text { OF PAGES } \\
\text { UL }\end{array}$ \\
\end{tabular}

19a. NAME OF RESPONSIBLE PERSON

19b. TELEPHONE NUMBER (Include area code) 